\title{
DIJALEKTIKA JEDENJA I GOVORENJA U DRAMAMA IVE BREŠANA
}

\section{GORDANA ČUPKOVIĆ}

\author{
Odjel za kroatistiku, Sveučilište u Zadru
}

\begin{abstract}
S aspekta kognitivne semantike razmatraju se primjeri u Brešanovim dramama u kojima se izravno kontrastiraju jedenje i govorenje. Riječ je o primjerima kojima se posreduju književni toposi i konvencionalni izrazi koji svoje utemeljenje imaju u konceptualnim metaforama: IDEJE SU HRANA i UM JE SPREMNIK i koji su i oblik specifičnoga tematiziranja jezika u novim pučkim komadima. Polazeći od klasičnih kognitivnih razmatranja (Lakoff i Johnson 1999) i Deleuzeova (2015) razmatranja dijalektike jedenja i govorenja kao odnosa unutarnjeg i vanjskog artikulira se dvojakost kulturnog modela gozbe - manifestacija razmjene ideja, svijesti i duhovnog te manifestacija hedonizma, unutarnjeg, nesvjesnog i tjelesnog - koja u Brešanovim dramama nalazi specifičan socijalnokritički oblik.
\end{abstract}

Ključne riječi: hrana, gozba, dramski jezik, konceptualna metafora, kognitivna semantika

\section{UVOD}

Scenska funkcija hrane analogna je funkciji verbalnih i neverbalnih znakova, hranom se tipiziraju likovi, njome se identificiraju grupe te ispoljavaju društvena hijerarhija i društveni kontrasti. Uprizorenje hrane posebno je razmatrano s historicističkoga i antropološkoga aspekta (posebno kod Shakespearea1, u nas kod Držića²). Historicistička distinkcija culinary - commensal (s jedne strane što jesti, u smislu sastojaka i pripremanja hrane, a s druge kako jesti, u smislu uključivanja interakcije ljudi i grupa (usp. Goldstein i Tigner 2016)) predstavlja hranu kao kulturnu formu, ali i kao kulturni model: kao manifestacija

${ }^{1}$ Usp. Goldstein i Tigner (2016), Fitzpatrick (2007).

2 Osvrt na literaturu o hrani u Držića može se naći u Ivanišević (2011). Hranom se i u Brešanovim djelima iskazuje društveni status: osiromašeni konte Florijan u Velikim manevrima nudi gostima maslaca i kruha kojim lijepi pukotinu na kanti u koju vrši nuždu (usp. Brešan 1997: 114), te razlike društvenih slojeva, primjerice konfrontacija težaka i građana u Velikim manevrima: Petrini je omiljena hrana "maništra i fažol s ovratinom" dok Katica “te spirine ne bi ila ni da me na kolinima moliš” (Brešan 1997: 137-138). 
tjelesnosti hrana jest i sastavnica konceptualizacije otjelovljena uma time osobito zanimljiva i s kognitivnoga aspekta, čemu u radovima o uprizorenju hrane dosad nije posvećivana znatnija pažnja. U Brešanovim je dramama na tragu naglašenoga tematiziranja jezika, kao odlike novoga pučkoga komada, već prepoznato "skretanje pozornosti na raskorak između svijesti i podsvijesti likova” te "dosizanje socijalnokritičkoga naboja” (Bobinac 2001: 75). Cilj rada je razmotriti specifičan segment tematiziranja jezika povezan s uprizorenjem hrane, konkretno dijalektiku jedenja i govorenja kojom se podcrtava razdjelnica unutra/ vani, svjesnog i nesvjesnog i koja se osim kao književni topos pokazuje i kognitivno utemeljenom. ${ }^{3} \mathrm{U}$ nastavku izdvajam pojedine književne primjere povezivanja hrane, mišljenja i govorenja, zatim dajem kognitivni okvir kako bi se izdvojena motivika i njezina univerzalna utemeljenost propitale u funkciji dramskoga jezika Ive Brešana.

\section{KNJIŽEVNA GOZBA}

Konvencionalne metafore konceptualizacije misli kao hrane te s tim u vezi i njezine dijalektičke povezanosti s jezikom podržane su književnim toposima, od antičke analogije književnoga stvaranja i priređivanja jela te poezije kao duhovne hrane (usp. Curtius 1998: 150) preko srednjovjekovne Augustinove analogije jedenja i učenja (povezanih poteškoćama u usvajanju kao neprobavljivošću) te Danteove metaforične gladi i žeđi (usp. isto: 150-152) do društvenog tematiziranja gozbe (posebno razvijeno u renesansnoj ideologiji banketa (usp. Goldstein i Tigner 2016)). Augustinove metafore pamćenja kao želuca duše, radosti i žalosti kao slatke i gorke hrane u želucu kognitivno su utemeljene u univerzalnome preslikavanju iz domene tijela na domenu apstraktnoga (um, emocije). Posebnu analogiju uspostavlja između tjelesne požude za jelom i pićem te požude tašte radoznalosti (Augustin 2007: 208) koja je i kao težnja za spoznajom obilježena dijaboličnošću. Eckhartova metaforika hrane - "unutarnje oko duše" i "analitičko oko razuma" (Eckhart 1989: 75) kognitivno je utemeljena u konceptualnoj metafori ZNATI JE VIDJETI. Povezanost uma i hrane jest i anatomska: enterički nervni sustav smješten u probavnom traktu u znatnoj je mjeri neovisan od središnjeg živčanog sustava te izravno potiče receptore u mozgu (usp. Vender 1998: 213, 565, 236-259).

U srednjovjekovnim i renesansnim tematiziranjima hrane možemo izdvojiti dvije okosnice: put prema unutra koji označava asketsko učenje uz hranu i dosizanje duhovnoga sklada, ali i nasljedovanje hedonističkoga filozofskog dijaloga Platonove Gozbe, te put prema vani koji među ostalim označava ispoljavanje nesvjesnog, tjelesnog i bestijalnog, ${ }^{4}$

\footnotetext{
${ }^{3}$ Pregledan je korpus od devetnaest drama (v. popis izvora na kraju rada) pri čemu su izdvojeni primjeri relevantni za temu rada.

${ }^{4}$ Hiperbolizacija tjelesnosti, kao odraz Bahtinova koncepta grotesknog realizma, nasljedovana je i iz narodne kulture, s dominantnim obilježjem "snižavanja”, preslikavanja duhovnog i apstraktnog na plan tjelesnog i materijalnog. Razjapljena usta kod Rabelaisa prepoznata su kao izraz otvorenoga tijela (Bahtin 1978: 355). S obzirom na to da je rad usmjeren na razmatranje kognitivnoga odnosa jedenja i govorenja, posebno u
} 
a koje je u kontekstu gozbe uobličeno izrazom jesti ili biti pojeden. Platonovski sklad jela i (raz)govora odslikava se u Moreovoj Utopiji, dok se kontrast jedenja i govorenja posebno ispoljava u Timonu Atenjaninu.

Sklad na Gozbi u kući Agatonovoj izrazno je vobličen analogijom hrane i govora (pohvale), Agaton momcima koji poslužuju jelo: "Predstavite samo da ste vi sada mene i sve ostale pozvali na čast, pa nas poslužujte da vas možemo hvaliti" (Platon 1985: 32), a misao je konceptualizirana kao hrana pa se može okusiti, Agaton Sokratu: "Spusti se do mene da okusim i od mudre misli koja ti je u predvorju na um pala" (isto).

Na filozofski sklad jedenja i govorenja navezuje se i društvena harmonija, prikazani sklad rodne i dobne hijerarhije u javnoj gradskoj blagovaonici Utopije. Čitanje prikladnog štiva uz ručak i večeru, "no ipak kratkog, da ne izazove dosadu" (More 2003: 269), potiče razgovor, ${ }^{5}$ čime se uz glazbu, slastice i mirisna ulja osigurava pouka i ugoda u jedenju, hedonizam je poželjan do mjere do koje ne postane štetan. ${ }^{6}$ Tijek jedenja usklađen je s tijekom probavljanja pa "ručkovi svršavaju brzo, dok večere protječu sporije budući da poslije ručka slijedi rad, a poslije večere noćni počinak koji oni smatraju blagotvornijim za zdravu probavu" (isto: 271).

U Timonu Atenjaninu laskavo govorenje kontrastirano je probavljanju neželjenog jela: mrzovoljni filozof Apemant kao opravdanje svog sudjelovanja u Timonovoj gozbi izravno kontrastira laskanje i meso koje je hrana (engl. flatter i meat):

Apemantus: I scorn thy meat;' 'twould choke me, for I should ne'er flatter thee. (Timon of Athens, I. 2, Shakespeare 1999: 1011)

Prezirem tvoje jelo; al ću se prije ugušiti njime nego da ti laskam. (Shakespeare 1970: 28, prijevod A. Šoljan)

Ujedno obrazlaže evolucijski i društveni kontrast jedenja ili bivanja jelom čime se uspostavlja analogija mesa i života (engl. meat - lives) čime se i podcrtava obilježje vremenskoga tijeka:

I wonder men dare trust themselves with men:

Methinks they should invite them without knives;

Good for their meat, and safer for their lives. (Shakespeare 1999: 1011)

okviru kulturnog modela gozbe kao društvene interakcije, aspekte karnevalizacije te s time povezana obilježja groteske dalje ne razmatram.

5 "Svaki ručak i večera počinju čitanjem štiva ćudorednog sadržaja, no ipak kratkog, da ne izazove dosadu. Starijima je ono povod da povedu pristojan razgovor, ne preozbiljan, ali ni neduhovit. Stariji ne zauzimaju čitavo vrijeme objeda svojim dugim monolozima, nego rado slušaju mlade. Dapače, namjerno ih izazivaju da upoznaju ćud i sposobnost svakog pojedinog među njima, što se otkriva u slobodnijem ozračju za stolom" (More 2003: 269).

6 “Od užitaka koje pruža tijelo prvo mjesto dodjeljuju zdravlju. Što se tiče slasti koja potječe od jela i pića, i svih sličnih naslada, njih valja tražiti, no samo radi zdravlja. Te stvari nisu ugodne same po sebi, nego jedino utoliko što predstavljaju otpor bolesti koja vreba u potaji. Zato mudar čovjek radije sprečava bolest nego da je liječi i radije izbjegava bol nego da traži ublažavajuće sredstvo" (More 2003: 305). "Odvratan je i jadan život u kojemu vlada glad, žeđ, svrbež, priroda je udesila da se ti užitci utažuju u prikladnoj mjeri hranom i pićem, koji čine ugodu, a ne kakvim lijekovima" (isto). 
Čudim se što se ljudi pouzdaju u ljude.

Na gozbu treba zvati ih bez noža:

Jelo se štedi, a čuva se koža. (Shakespeare 1970: 28)

\section{JEDENJE I GOVORENJE}

Konvencionalne i petrificirane metafore, rasprostranjene u govoru i posredovane književnim djelima, kao i one inovativne, pjesničke, utemeljene su u univerzalnim konceptualnim metaforama.? Tipično dvodomensko preslikavanje koje obilježava primarne metafore, s izvorne domene (koja je senzomotorna domena i domena konkretnoga) na ciljnu domenu (koja je domena subjektivnoga iskustva (usp. Lakoff i Johnson 1999: 58) i domena apstraktnoga), utemeljeno je na postavci da apstraktne entitete ljudski um opojmljuje uspostavljanjem poveznica s osobinama konkretnih entiteta, u čemu je sadržana i hipoteza o evolucionizmu razuma. ${ }^{8}$ Kognitivna razmatranja otjelovljenog uma, uobličena primarnim konceptualnim metaforama UM JE TIJELO i UM JE SPREMNIK, posebno sU koncentrirana na konceptualiziranje apstraktnog mišljenja posredstvom konkretnih radnji hranjenja/jedenja pa se um koji dobro funkcionira konceptualizira kao zdravo tijelo. Tragom toga Lakoff i Johnson popisuju daljnja konceptualna preslikavanja: IDEJE SU HRANA, DOBIVANJE IDEJA JE JEDENJE, LOŠA MISAO JE ŠTETNA HRANA, RAZMATRANJE JE ŽVAKANJE, PRIHVAĆANJE IDEJA JE GUTANJE I PROBAVLJANJE, NEPRIHVATLJIVE IDEJE SU NEPROBAVLJIVE, ARTIKULIRANJE IDEJA JE PRIPREMANJE HRANE, KOMUNIKACIJA JE HRANJENJE, BITNE IDEJE SU MESO (Lakoff $\mathrm{i}$ Johnson 1999: 241); sve se navedene metafore objedinjuju preslikavanjem MIŠLJENJE JE JEDENJE.

Misao se konceptualizira i u terminima simboličnog, kao jezik: MIŠLJENJE JE JEZIČNA AKTIVNOST (govorenje ili pisanje), IDEJE SU RIJEČI I REČENICE (isto: 244), čime se označava izvanjštenje misli i artikulirana reprezentirana struktura, pomoću linearnih sekvenci (artikulirani glasovi i slova). Time se u području konceptualizacije apstraktnoga uma uspostavlja analogija funkcija govorenja i jedenja.

Razmatrajući prožetost semiotičkih, materijalnih i društvenih tokova Deleuze i Guattari problematiziraju pojmove metafore i metonimije premještajući ih iz jezične (konstativne) u uporabnu (performativnu) perspektivu. Umjesto hijerarhijskoga sustava kakav zastupaju rani kognitivisti, uspostavljaju sliku uma kao karte prelijevanja s riječima-konceptima kao linijama. Organizacija uma, kao organskoga stratuma i kompleksnoga središta, predočena je slikom predljudske juhe u kojoj su ljudi uronjeni rukama i licem kao reprezentantima izraza/djelovanja i sadržaja (Deleuze i Guattari 2013: 75).

\footnotetext{
${ }^{7} \mathrm{O}$ odnosu pjesničke/inovativne i konvencionalne metafore prema konceptualnoj metafori, kao odnosu izraza i mentalnog obrasca na kojem se izraz temelji, usp. Žic Fuchs (1992-1993) i Stanojević (2013). O kognitivnoj poetici usp. Biti i Marot Kiš (2008).

8 "Darwinizmom razuma" Lakoff i Johnson nazivaju osobinu ljudskoga uma da i u svom najapstraktnijem obliku ne transcendira, već iskorištava ljudsku animalnu prirodu (1999: 4). Anonimni recenzent podsjetio me je i na poveznicu s evolucijskom semantikom i Kronasserovim zakonom, prema kojemu se semantičke promjene odvijaju jednosmjerno i taj je smjer analogan tipičnom smjeru metaforizacije: konkretna značenja predstavljaju polazište za konstrukciju apstraktnih (usp. Barcelona 2003: 174).
} 
Interpretirajući djela Lewisa Carrolla Deleuze posebno razmatra dijalektiku govorenja i hranjenja, kao alternativu vanjskoga i unutarnjeg i kao dijalektičku artikulaciju razlike tijela i jezika: govorenje je izvanjštenje i predstavljeno, a hranjenje pounutrenje i tjelesno (Deleuze 2015: 28). Postulat jesti ili biti pojeden na Alisinoj krunidbenoj gozbi izdvojen je kao "operacijski model tijela" (način kako tijela supostoje jedna u drugima) (isto: 27). Posebno je izdvojeno jedenje riječi kao koncept u kojem se pretapaju unutarnje i vanjsko, predstavljaju ih slučajevi govornih poremećaja, punih usta i mucanja, kad izgovorene riječi dolaze do slušatelja iskrivljene, "privučene dubinom tijela" (isto). Pretapanje unutarnjeg i vanjskog može se pratiti i u primjerima osobitoga obratnog preslikavanja, u kojima je puno tijelo ciljna domena opojmljivanja apstraktnoga govorenja i apstraktne spoznaje. Takvi su primjeri u Brešanovim dramama odrazi osobitoga kriticizma, kao rezultanta poigravanja s pučkim, ujedno su u skladu s osnovnom premisom otjelovljenosti ljudskoga uma: "razum nije bit koja nas odvaja od drugih živih bića, već nas smješta u kontinuum s njima” (Lakoff i Johnson 1999: 4).

\section{HRANA I GOVOR U BREŠANOVIM DRAMAMA}

S obzirom na navedenu opreku unutra/vani i konceptualne metafore IDEJE SU HRANA i UM JE SPREMNIK, u Brešanovim se djelima može uspostaviti opreka značenjskih skupina: hrana na stolu - hrana u ustima i u trbuhu. Izdvojenim se značenjskim skupinama manifestiraju različite jezične funkcije te dijalektički povezane inačice kulturnoga modela gozbe.

\section{HRANA NA STOLU}

Hrana na stolu zaprema apelativnu predstavljačku funkciju, postaje kod kojim se utječe na sugovornika. Kao ishodišna domena $u$ konceptualizaciji apstraktnoga hrana je i u toj funkciji u napregnutom suodnosu između pokušaja reprezentiranja svijesti te dohvaćanja i ispoljavanja nesvjesnoga. Kulturni model gozbe (sa značenjskim poljima svečane večere, obiteljskog okupljanja, pogrebnog okupljanja, pa i predstavljanja) u Brešanovim dramama mjesto je gdje se svečani (raz)govor visokoga stila kao reprezentant svijesti zbog prožetosti političkom frazom $s$ jedne te vulgarnom pučkom frazom s druge strane izokreće $u$ kolektivnu negaciju govora koja je istodobno i afirmacija jedenja.

Obrazlažući postavke svoga kazališnoga sustava Brešan kao osnovni putokaz promišljanja dramske situacije navodi Hegelovu trijadu (Brešan 1996: 4): klasična ideja ostvaruje se u svojoj suprotnosti, spuštena u vulgarnu svakodnevicu, proizvodeći u pretopljenom prostoru nova značenja ${ }^{9}$ i to u spoju visokog i trivijalnog, sudbinskog i slučajnog (isto: 6). Suprotnost je sadržana i u konceptualizaciji ideje kao hrane; survavanje balansa između

\footnotetext{
${ }^{9}$ Kognitivna teorija konceptualne integracije upravo je utemeljena na postavci kako se iz dvaju ili više ulaznih prostora povezanih zajedničkim generičkim prostorom stvara pretopljeni prostor novih značenja koja u ulaznim prostorima nisu zastupljena (usp. Fauconnier i Turner 1998).
} 
okrepe i hedonizma, govorenja i jedenja, podržano konceptom otjelovljena uma te materijalizacije i razotkrivanja nesvjesnog, u vulgarnoj svakodnevici iznjedruje klišeje o govorenju i hrani, s potencijom učitavanja kritičkih značenja.

Reprezentativnost koja se ogleda u konvencionalnoj metafori knjige kao hrane (koja je utemeljena u konceptualnoj metafori IDEJE SU HRANA) u imitaciji pučkoga govora preobraća se u klišeiziranu metaforu hrane na stolu kao knjige, obratom preslikavanja (s apstraktnog na konkretno umjesto tipičnog preslikavanja s konkretnog na apstraktno) na razini likova u drami parodira se koncept filozofske gozbe dok se na razini autora i gledatelja izruguje "zdravorazumski" koncept pučkoga nauka (kao tipičnog preslikavanja s greškom analogno jezičnim pogreškama te začudnom, kritičkom i komičkom preplitanju registara na planu izraza). Zvone u Nihilistu iz Velike Mlake zove za stol Sandru, koja čita i nije gladna:

Sandra: Nisam gladna, nono.

Zvone: Je, najila si se velike pameti iz tega libra... Homo, homo, dico! Iz ovih libara na stolu triba se učit. (Brešan 1997a: 167; sva su podcrtavanja u citatima autoričina)

Parodija gozbe naglašena je dobnom obilježenosti govora (nono-dico).

Konfrontacija pučkog i knjiškog nauka, pri čemu se pučki nauk izjednačuje s jelom, vidljiva je i u pjevanim desetercima iz Arheoloških iskapanja: "Više vridi pečena kokoška, / Nego cila znanost arkološka" (Brešan 1989: 125).

U apelativnoj funkciji uvjeravanja hrana se pojavljuje kao sredstvo dobivanja potpisa, za podržavanje političke karijere pojedinca i za podržavanja Nečastivog. U Juliju Cezaru scenski radnik Landeka vabi potpis od čistačica za svoju kandidaturu za saborskog zastupnika pokazujući kobasice, sir, salamu i "druge delikatese” (Brešan 1997: 184), dok u Nečastivom prije potpisivanja ugovora konobari na pladnjevima donose "jaganjca božjeg" (Brešan 1978: 166) na kanibalsko trganje rukama.

U konceptualnoj metafori IDEJE SU HRANA utemeljena je konvencionalna analogija hrane / teme govora i govornoga subjekta, u Juliju Cezaru Šurka se nad hranom pita: "A šta ovo ima reć?" (Brešan 1997: 184), te izjednačavanje jedenja i govorenja/slušanja:

Svračak: Pa mi nismo rekli da nećemo poist...

Landeka: Kako niste rekli? Rekli ste. Čim sam zaustija da počnem govorit, oma ste se uskopistili i stavili mi na znanje da ćete rađe gladovat negoli mene slušat.

Pirija: Ma nije baš tako... mi bi te isto posli marende poslušali...

Šurka: Ma ko je reka da te nećemo poslušat. Pa jesmo li pristali bit članovi SPAS-a, oli nismo... Je li tako, Čuča?

Čuča: Ma naravski! Govori šta god te voja, samo nam to ostavi! (Brešan 1997: 185)

U Nečastivom na Filozofskom fakultetu govorenje i užitak (jedenje i pijenje) kontrastiraju se posredstvom enciklopedijskoga znanja (o tekstovnoj predaji) pa Fausner evocira evanđeosko Slovo: “U početku svega bijaše užitak" (Brešan 1979: 167), a član Komiteta klišeizirano se referira na postavke marksizma: "Da je Marx ovako dobro jeo i pio, ne bi mu padala na pamet diktatura proleterijata” (Brešan 1979: 169). 
U neomarksističkoj kritici komunizma već je uočeno kako se propagiranjem ovladavanja sviješću, za što ljudski um po prirodi nije osposobljen, dovodi čovjeka u viziju ranosrednjovjekovnoga pakla (Chukhrov 2017), koji nije fantastični prostor sablasti, već realni prostor suzdržavanja, takav je svijet unutarnjeg pakla i Shakespeareovih junaka. Lukács naglašava formiranje klasne svijesti upravo putem posredovanja, projiciranim svijetom prevladava se neposrednost zbilje i približava svijesti o sebi pa je klasna povijest predstavljačka: ljudi kao autori i glumci svoje vlastite drame (Lukács 1977: 246). Brešan predstavljačku svijest parodira: ideološkim praznogovorom koji popunjava referencijalnu funkciju (u Predstavi Hamleta proklamiranu proletersku svijest posebno tematizira radio emisija), ${ }_{10}^{10}$ nemogućnošću govora (gluhonijemi vodoinstalater u Nečastivom: "Kad se taj vodoinstalater probudi u vama, vaša će se svijest rasplinuti u prostoru i nestati” (Brešan 1979: 172)) te hedonističkom varijantom predstavljanja pri čemu se predstavljanje umjesto propagiranja ovladavanja sviješću dovodi u komplementarni odnos s grlom (pijenjem) i trbuhom (jedenjem) te se istodobno relativizira postavka klasnih razlika (hrana buržoazije-hrana proletera)," posebno vobličeno folklornom predstavljačkom pobudnicom: "ne moš prestavljati suva grla i na prazan želudac, donesi: pršut, štrucu kruva i dvi kapule" (Brešan 1979: 61).

Inflacija predstavljanja u Predstavi Hamleta (četiri predstavljačka teksta unutar Hamleta (usp. Čale Feldman 1997: 323-324)) dopunjuje se hiperpredstavljanjem uprizorene hrane (hrana na sceni, hrana kao tema govora, probavljanje na sceni i probavljanje kao tema govora) čime se naglašava funkcija kazališta kao "opasnoga doslovnoga naturalističkog zrcala" (Čale Feldman 1997: 323). Shema analogije između predstava i predstavljanja hrane u Predstavi Hamleta, s Bukarom kao antijunakom klasične kazališne predstave te junakom hranjenja i hranidbenog lanca, čije ime je i etimološki spremnik (pića), može se prikazati ovako:

${ }^{10}$ Leksem svijest učestalo se ponavlja u političkoj frazi: "o izgrađenoj socijalističkoj svijesti kod stanovništva ovog kraja" (Brešan 1979: 25), "i jačanju socijalističke svijesti u redovima seljačkih masa” (isto: 26), "kod nekih klasno nesvjesnih i reakcionarno raspoloženih pojedinaca” (isto: 40-41), pa je i proklamirano kazalište: “jedan od oblika žive narodne svijesti" (isto: 73).

${ }^{11} \mathrm{Na}$ klasne razlike referira se načinom jedenja:

Bukara: Nego šta si ti tija, da ga milujem onako po gospodsku ki ti: komadić po komadić, pa pinjurom u usta. Tako, brte, ide buržoazija. Ja ti volim kad ga šakom zgrabim, en ti suze Gospine, pa ga iščupam iz janjca i onda trgnem zubima. A svaku malo zalijem čašom vina. To je iće, a ne ono čvokanje pinjurom ki kokoš kljunom! (isto: 30),

kao i onim što se jede:

Mačak: Ćaćo moj, Polonije, eno Omelija, tvoja ćerka, a moja sestra, pršuta nam nosi.

Bukara: Omelijo, nariži kralju, svome gospodaru, dvi fete tamo di je crveno! [...]

Bukara: Slušaj ti, Šime! Je li tebi jasno da mi tute prestavljamo monarhiju, a ti zadnju rupu na svirali. I red je, brte, da se mi kripimo, a ti da brstiš (isto: 63). 


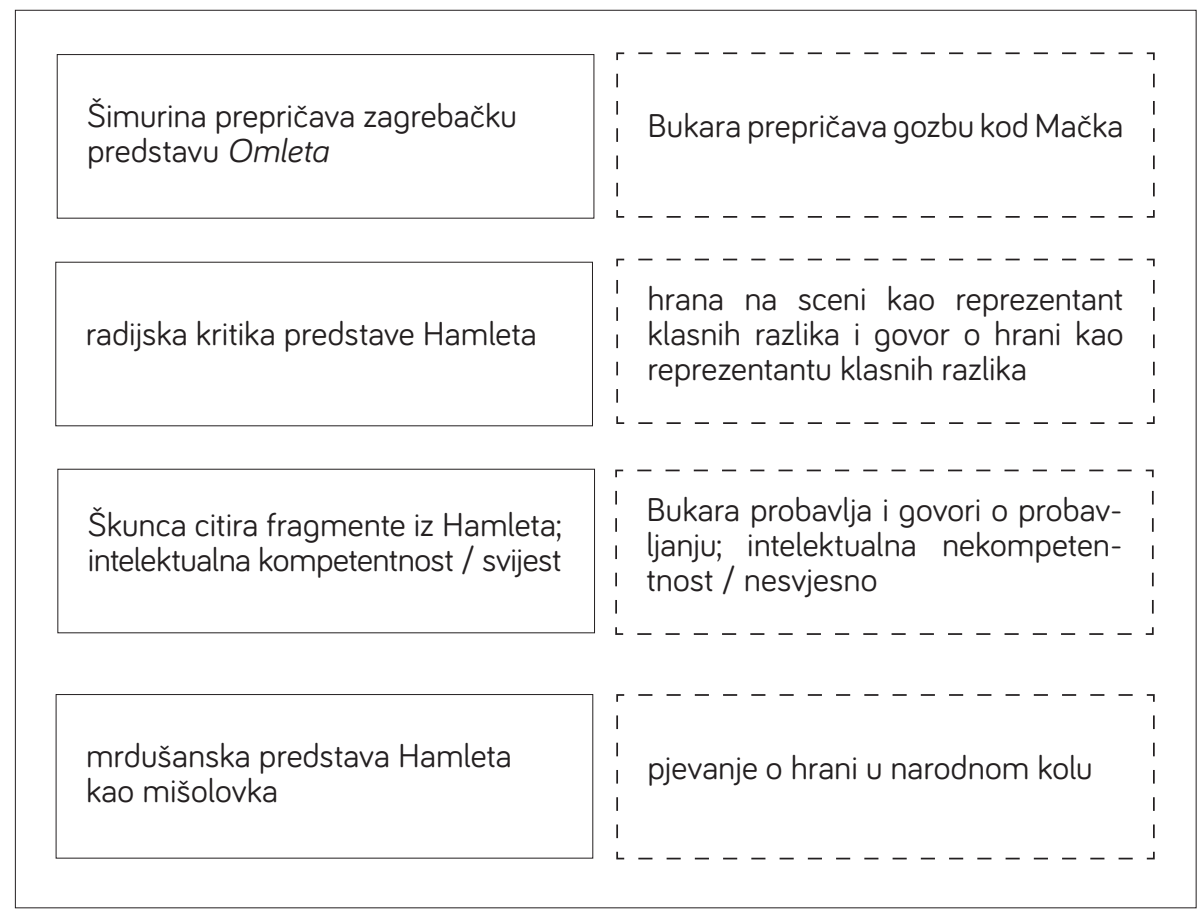

U svim je primjerima hrana na sceni povezana i s njezinim eksplicitnim tematiziranjem: uprizorena hrana (kao stvarna hrana na sceni i kao govorenje o hrani) rasteže se između dvaju suprotstavljenih polova, od vani prema unutra, od predstavljačke do žderačke funkcije.

\section{HRANA U USTIMA I U TRBUHU}

Hrana u ustima i u trbuhu popunjava ekspresivnu funkciju, prvenstveno u smislu ispoljavanja unutarnjeg i nesvjesnog, tipično govorno obilježje jest eliptičnost kao posljedica ometanja govora hranom ili probavom i kao manifestacija dijaboličnog, bestijalnog i tjelesnog; govor primarno ne upućuje na vanjsko stanje stvari, već je govorni subjekt i objekt svoga vlastitoga govora (usp. Pfister 1998: 173). Posredstvom preslikavanja iz ishodišne domene unutarnjeg, ograđenog prostora, spremnika, uspostavlja se analogija između trbuha, usta i uma. Konceptualna metafora UM JE SPREMNIK pretpostavka je materijalizacije uma, posebno njegovih sakrivenih dijelova, nesvjesnog do kojeg se dolazi jedenjem i probavljanjem i koje prenaglašenom ispunjenosti označava nemogućnost intelektualnog djelovanja.

Iznimno referencijalno upućivanje na drugog hranom u ustima vidljivo je u označavanju dijaboličnog, u Potopljenim zvonima prota Sveto jede svoju nacionalno obilježenu gibani$\mathrm{Cu}^{12}$ i govori Zlodri:

${ }^{12}$ Radnja drame odvija se nakon Prvoga svjetskog rata i utemeljena je na stvarnom novinskom izvješću, no vidljive su analogije sa suvremenosti u kojoj je drama nastala (devedesete godine 20. stoljeća), drami 
Prota Sveto: I kad je saznao da o vama kola glas da ste prodali dušu đavolu... (prekine se da bi progutao oveći zalogaj). (Brešan 1997: 28)

Naglašenim tematiziranjem probavnih smetnji hrana se kontrastira intelektu (kao razumu i svijesti); takvim se postupkom i obeznačuje karakter likova, točnije kontrastira njihov društveni značaj s prirodnim značajem. Bukara u Predstavi Hamleta podriguje i naglašava kako nije pokvario želudac, nego se prejeo i prepričava kako su jučer "potarašili cilo janje [...] pa mi danas vas dan od toga ništo unutra krči, vari se, primeće, šta ti ga ja znam. I niki zrak izlazi iz mene i gorika i dolika. Vidi štumak, kako mi se naduja!” (Brešan 1979: 30).

Ždrapić iz Smrti predsjednika kućnog savjeta jede rableovski, njegova pojava u svakoj je sceni popraćena prenaglašenim nabrajanjem (pojedene, donesene/predstavljene) hrane. Probavljanje je njegovo karakterno obilježje, a podrigivanje $i$ ispuštanje vjetrova znak prepoznavanja:

Ždrapić: Znate, drugovi, ja, da budem iskren, nemam nikakvih većih zaduženja, osim što radim kao računovođa u poduzeću. Ali, moram vam reći da kod mene poslije ručka probava jako dugo traje... Dok se, znate, sva ta hrana provari u želucu, dok prođe kroz crijeva, pa dok ispustim iz sebe sve one plinove i suvišne supstance, ja nisam ni za što sposoban, osim za drijemanje. I tek se negdje predveče malo razbistrim, ali onda brzo iza toga dođe večera, pa sve iznova. To je, znate, medicinski dokazano, dok čovjek probavlja hranu, nije u stanju da vrši nikakve veće intelektualne napore. Jednom riječi, ovo zaduženje nikako nije za mene. (Brešan 1979: 189)

Ždrapićev se govor tijekom probavljanja i polusvijesti koju ono izaziva posve reducira na ispuštanje neartikuliranih zvukova:

Ždrapić: Abrkljrmnhrrrrrrrr....

Bostanac: Šta, šta? Šta si reka?

Ždrapić: Abrkljrmnhrrrrrrrr....

Bostanac: Stane...Stane...Šta mu je? Da ga nije nešto uvatilo u glavu?

Stana: Ma nije mu ništa. To je svaki put tako kad se priždere... više od dvi ure ne zna za se. (Brešan 1979: 227-228)

Potpuna redukcija govora tematizira se naglašeno ispunjenim ustima; u "gozbi" kojom završavaju Arheološka iskapanja fiziološke radnje trganja i jedenja pečenog ovna posve zamjenjuju govor:

suvremena nacionalna i vjerska napetost posebno je izražena hranom pa gostioničar provocira prota Svetu, koji je stanovnike dalmatinskog otoka na njihov poziv došao preobratiti na pravoslavlje:

Gregov: Je li po voji malo obotnice na salatu?

Prota Sveto: Hobotnica? Je li to ona avetinja sa osam nogu? Beži, beži, bre! To mi se gadi i da gledam.

Gregov: A onda da vam ispečem malo škampi?

Prota Sveto: Škampi? Ona čudovišta šta liče na akrape? Šta je tebi, čoveče? Hoćeš li da se odmah tu ispovraćam?

Gregov: A ča ja morem? Nima ništa drugo. Pojilo se. Sad smo prid zatvaranjem.

Prota Sveto: Eh, vidim ja da bih po tebi crko od gladi. Sva sreća šta mi je moja Sidonija stavila u torbu komad gibanice za poputbinu... (Brešan 1997: 27-28). 
Seljaci se okupe oko stola i počnu rukama trgati komade ovna i jesti. Prizor pomalo poprima groteskne i infernalne oblike. U najvećoj tišini, potpuno koncentrirani na jelo, seljaci s pohlepom u očima, izmašćenih ruku i obraza, čupaju zubima komade mesa. Jedino što se čuje jest mljackanje, lomljenje košćica i grgoljenje vina koji klizi niz grlo. To postaje sve glasnije i ubrzanije. (Brešan 1989: 127-128)

U "najvećoj tišini” govore oči (pohlepom) te izmašćene ruke i obrazi čime se simbolična jezična artikulacija, obratnim preslikavanjem s apstraktnog na konkretno, vraća otjelovljenosti kao ishodištu, "puno tijelo"13 zauzima mjesto hijerarhizirane artikulacije apstraktnog. Pritom koncept punoga tijela nije sukladan konceptu praznoga uma, već naprotiv, označavanjem otjelovljenosti označuje ispunjenost materijalizirana uma. Gledano prema unutra, jedenje hrane postaje jedenje jezika. Gledano prema vani, unatražno odvijanje povijesti popraćeno je unatražnim razvojem jezika: od artikuliranoga govora prema nemuštosti, u kojoj scena postaje analogna sceni s početka Kubrickove Odiseje. Naglašenim konceptom ubrzanja žderačkih radnji - "to postaje sve glasnije i ubrzanije" - otkriva se i Platonova dimenzija "čistog postajanja bez mjere", na koju se referira Deleuze, kao postajanja koje se manifestira u kretanju, tijeku riječi i “mahnitog govora” (Deleuze 2015: 8) te se kreće u oba smjera uzrokujući podudaranje budućnosti i prošlosti, potiranjem imenskih riječi, stanki i mirovanja označava se i iščezavanje identiteta iz "jastva, svijeta i Boga" (isto: 9). Mahnita nemuštost u nultoj točki svevremena pokazuje se završnim produktom konceptualnog pretapanja jedenja i govorenja.

\section{ZAKLJUČAK}

Izdvojene značenjske skupine tematiziranja jedenja i govorenja u dramskom jeziku Ive Brešana: hrana na stolu, kao predstavljena hrana i hrana koja predstavlja, i hrana u ustima i u trbuhu, kao probavljana hrana, demonstriraju klišeizirano kontrastiranje književne/inovativne i konvencionalne metaforike te potvrđuju bitna obilježja konceptualizacije otjelovljena uma posebno uobličena konceptualnim metaforama: UM JE SPREMNIK i IDEJE SU HRANA. KaO što se na književnom polju u proučavanim dramama klasične književne teme sudaraju s vulgarnom svakodnevicom tako se na konceptualnome polju vrši obrat preslikavanja: od apstraktnog prema konkretnom, materijalnom. Dijalektika jedenja i govorenja odvija se paralelno s predstavljačkim strategijama: od obavijesno ispražnjene ideološke fraze, popraćene hranom na stolu, do konkretne nemuštosti, uzrokovane hranom u ustima, koja vodi i do dosizanja punoga tijela uma. Time hrana zadobiva svoju dramsku funkciju i izvan okvira grotesknog; posredovanjem kognitivno utemeljenih značenja pridonosi rasvjetljavanju univerzalne segmentiranosti ljudskoga uma.

\footnotetext{
${ }^{13}$ Puno tijelo Deleuze i Guattari predstavljaju kao rezultantu rastepnuća subjekta: "Zašto se ne bi hodalo na glavi, pjevalo sinusima, vidjelo kožom, disalo trbuhom: jednostavna Stvar, Entitet, puno Tijelo, nepokretno Putovanje, Anoreksija, kožno Viđenje, Joga, Krišna, Ljubav, Eksperimentiranje. Ondje gdje psihoanaliza kaže: stanite, i ponovo nađite svoje ja, treba reći: idemo još dalje, još nismo našli svoje Tijelo, još nismo dovoljno rastepli svoje ja. Zamijenite anamnezu zaboravom, interpretiranje eksperimentiranjem. Pronađite svoje tijelo bez organa, umijte ga načiniti, to je pitanje života ili smrti, mladosti i starosti, žalosti i veselja. To je mjesto gdje se sve odvija" (Deleuze i Guattari 2013: 171).
} 


\section{IZVORI}

Brešan, Ivo. 1979. Groteskne tragedije. Zagreb: Izdanja Centra za kulturnu djelatnost SSO Zagreba.

Predstava Hamleta u selu Mrduša Donja (groteskna tragedija u pet slika)

Nečastivi na Filozofskom fakultetu (moralitet u sedam slika)

Smrt predsjednika kućnog savjeta (burleska u devet slika)

Svečana večera u pogrebnom poduzeću (scenska igra u est slika s prologom)

Brešan, Ivo. 1989. Nove groteskne tragedije, Četiri dramske varijacije klasičnih tema. Zagreb: Cekade.

Viđenje Isusa Krista u kasarni V. P. 2507

Arheološka iskapanja kod sela Dilj (Groteskni misterij u tri dijela)

Anera (Tragikomedija u pet činova)

Hidrocentrala u Suhom dolu (Drama u pet činova s Intermezzom)

Brešan, Ivo. 1993. Tri drame. Zagreb: Znanje.

Ledeno sjeme (Drama u dva dijela, osam slika)

Stani malo, Zvonimire (Povijesna komedija ili komedija povijesti u 11 slika)

Brešan, Ivo. 1997. Spletke. Zagreb: Naklada DHK.

Potopljena zvona (Groteska u 10 slika)

Veliki manevri u tijesnim ulicama (komedija u dva dijela, 14 slika)

Julije Cezar (Suvremena tragedija u 10 slika)

Brešan, Ivo.1997a. Utvare. Zagreb: Znanje.

Kratki kurs dugog propadanja (Četiri jednočinke):

Mastodont

Autodenuncijacija

Kako je drug Jere Pičak isključen iz Saveza komunista

Egzekutor

Utvare (Dramske permutacije u 15 scena)

Nihilist iz Velike Mlake (Komedija u 5 činova)

\section{NAVEDENA LITERATURA}

Augustin, Aurelije. 2007. Ispovijesti. Zagreb: Kršćanska sadašnjost.

Bahtin, Mihail. 1978. Stvaralaštvo Fransoa Rablea i narodna kultura srednjega veka i renesanse. Beograd: Nolit.

Barcelona, Antonio. 2003. Metaphor and Metonymy at the Crossroads. A Cognitive Perspective. Berlin, New York: Mouton de Gruyter. https://doi.org/10.1515/9783110894677

Biti, Marina i Danijela Marot Kiš. 2008. Poetika uma. Zagreb: Hrvatska sveučilišna naklada.

Bobinac, Marijan. 2001. "Poetika i dramska praksa Ive Brešana”. Republika 57/9-10: 51-87.

Brešan, Ivo. 1996. “Osnovna načela moga kazališnog sustava”. Republika 52/1-2: 3-16.

Chukhrov, Keti. 2017. “Lijeve zablude u tumačenju političke ekonomije povijesnog socijalizma” [predavanje]. Fališ, 9. rujna, Šibenik. 
Curtius, Ernst Robert. 1998. Europska književnost i latinsko srednjovjekovlje. Zagreb: Naprijed.

Čale Feldman, Lada. 1997. Teatar u teatru u hrvatskom teatru. Zagreb: Naklada MD, Matica hrvatska.

Deleuze, Gilles i Félix Guattari. 2013. Kapitalizam i shizofrenija, 2. Tisuću platoa. Zagreb: Sandorf, Mizantrop.

Deleuze, Gilles. 2015. Logika smisla. Zagreb: Sandorf, Mizantrop.

Eckhart, Maister. 1989. Knjiga božanske utjehe. Zagreb: Naprijed.

Fitzpatrick, Joan. 2007. Food in Shakespeare. Early Modern Dietaries and the Plays. Aldershot: Ashgate Publishing, Ltd.

Fauconnier, Gilles i Mark Turner. 1998. "Conceptual Integration Networks”. Cognitive Science 22/2: 133187. https://doi.org/10.1016/S0364-0213(99)80038-X

Goldstein, David B. i Amy L. Tigner, ur. 2016. Culinary Shakespeare. Staging Food and Drink in Early Modern England. Pittsburgh: Duquesne University Press.

Ivanišević, Jelena. 2011. "Lačan ne haje toliko za ljubav. Gastronomija Dunda Maroja između srednjovjekovlja i renesanse". Anali Dubrovnik 49: 9-25.

Lakoff, George i Mark Johnson. 1999. Philosophy in the Flesh. New York: Basic Books.

Lukács, Georg. 1977. Povijest i klasna svijest. Zagreb: Naprijed.

More, Thomas. 2003. Utopija. Zagreb: Nakladni zavod Globus.

Pfister, Manfred. 1998. Drama. Zagreb: Hrvatski centar ITI.

Platon. 1985. ljon, Gozba, Fedar. Beograd: Beogradski izdavačko-grafički zavod.

Shakespeare, William. 1970. Timon Atenjanin. Zagreb: Matica hrvatska.

Shakespeare, William. 1999. The Complete Works of William Shakespeare. Hertfordshire: Wordsworth Editions.

Stanojević, Mateusz-Milan. 2013. Konceptualna metafora. Zagreb: Srednja Europa.

Žic Fuchs, Milena. 1992-1993. “Konvencionalne i pjesničke metafore”. Filologija 20-21: 585-593.

\section{THE DIALECTICS OF EATING AND SPEAKING IN IVO BREŠAN'S PLAYS}

This paper investigates the contrast of eating and speaking from the theoretical standpoint of cognitive semantics, as it appears in plays written by Ivo Brešan. These examples are mediated by literary archetypes and conventional expressions based on the IDEAS ARE FOOD and THE MIND IS A CONTAINER conceptual metaphors. They are also a specific way to problematize language in new folk plays. Starting from the classical cognitive view (Lakoff and Johnson 1999), and Deleuze's (2015) dialectics of eating and speaking as a relationship between the inner and the outer, the paper articulates the duality of the cultural model of banquet: manifestations of the exchange of ideas, consciousness and spirituality, and manifestations of hedonism, inner, unconsciousness and physical. This duality in Brešan's plays has a specific social-critical form.

Keywords: food, banquet, language of drama, conceptual metaphor, cognitive semantics 